\title{
Effect of Distribution Channel Strategies on the Performance of Banks
}

\author{
Dickson Ben Uche ${ }^{\mathrm{a}}$, Jane Nwakaego Anene ${ }^{\mathrm{b},{ }^{*}}, \&$ Emezue Leonard Nnabugwu ${ }^{\mathrm{c}}$ \\ ${ }^{a}$ Department of Marketing, Evangel University, Akaeze, Nigeria \\ ${ }^{b}$ Department of Marketing, University of Nigeria, Enugu Campus, Nigeria \\ ${ }^{c}$ Centre for Research, University of Nigeria, Enugu Campus, Nigeria
}

\begin{abstract}
Effective distribution channel strategy selection, application, and management does not only help to meet the shopping needs and habits of the target customers efficiently under the cost restraints of the seller; they must also lessen the drawbacks caused by distribution channel conflicts such as double downgrading. This study evaluated the effect of distribution channel strategies on the performance of commercial banks in Nigeria. The objective of the study specifically was to identify the distribution channel strategies adopted by commercial banks in Nigeria and to determine the effect of the distribution channel strategies adopted on the performance of the bank. The study adopted a descriptive survey research design. The population of the study was 43 management staff of five commercial banks operating in Nigeria. Questionnaire was used as the tool for data collection. The data was analyzed and presented using percentages, mean and standard deviation. The study found that the branch network, electronic banking and multiple distributions were used by the banks. Marketing strategies being employed by the banks were aggressive marketing, mass marketing and value marketing, the study further found that the adopted distribution channel strategies have a significant effect on the performance of the banks. It was recommended among other things that; commercial banks should adopt those marketing distribution strategies that ensure the performance of the bank is improved and do away with those which adds costs so that the banks can compete effectively with the others and that they should embrace the concept whole heartedly by adopting electronic banking as already the battle for the banks is technology usage which should be one which offers customers more features
\end{abstract}

Keywords: marketing, distribution channel, strategies, performance, commercial banks

\section{Introduction}

As a result of deregulation, new technology and changing consumer behavior, the competition in the banking sector is getting fiercer. In the banking sector the intensified competition has recently resulted in a number of banks launching non-bank financial services through their branches as well as insurance companies and other financial companies opening banks. The battle for the customers is, however, also fought through new electronic distribution channels. Greenland (2004) predicted that in the foreseeable future the branch network will remain the main channel for retail banks. However, despite these predictions, the electronic distribution channels available for financial service companies world-wide force the banks to make a number of strategic distribution channel decisions.

According to economic distribution channel theory, the "ideal" distribution system or the normative distribution channel can be determined by exploring what the consumers want in terms of service outputs from the distribution channel, how much they are willing to pay for a given service level, how the services can be provided to them, and what the costs of the alternative distribution channels are (Stern et al., 2006). As a result they argue that it can be determined which distribution system most efficiently meets the customers' wants and it can be pointed out that the distribution channel strategy adopted by a firm should take a customer perspective and analyse the output from the commercial part of the different distribution channels and relates it to the customers' costs and benefits from the different levels of service output offered by the available distribution channels (Cohen et al., 2013).

According to rational channel planning models (Stern et al., 2006), commercial banks should identify profitable customer segments attracted to branch banking, telephone banking, PC banking and Internet banking or combinations thereof. Based on this knowledge, they have to decide which distribution channels they want to offer their present and

\footnotetext{
* Corresponding author.

E-mail address: joy.chris-nnamchi@unn.edu.ng
} 
future customers. As a result of these, banks should predict both the consumer acceptance of these distribution channels and the dominating distribution channel strategies of their competitors. However, Stern et al., (2006) further observe that the problems of the commercial banks are even more complex because the different distribution channels have different cost structures and different degrees of face-to-face interaction. This creates an interrelationship of distribution channel strategy and the other elements of the bank's marketing mix, such as pricing, level of personal service, and the array of services offered. Hence banks should be able to identify appropriate distribution strategies that will give it necessary competitive advantage.

The adaptation process in the commercial banking sector is rendered visible by the adoption and promotion of electronic distribution channels. According to Cohen et al., (2013), this influences the future distribution channel structure in two ways. First, the cost of using them is different from that of other available distribution channels, and the service output they provide to the consumers is different from the service output provided by the branch-based channels. Some banks have customers that ask for the electronic channels; they consider them to be important distribution channels and are quick to introduce and promote them to their customers. Other banks have only a few customers who want to use the electronic channels and these banks are more hesitant to introduce them. Further, the electronic distribution channels influence the consumers. Many of them are exposed to the promotion of the electronic distribution channels. Some of these customers invest time and resources in becoming PC literate and in getting to know the Internet or they learn to use the telephone for conducting their banking activities. Other consumers do not want to use the telephone for banking services; they do not become PC literate and do not get familiar with the Internet. These different customer segments are not likely to have the same wants and are not likely to be willing to pay the same price for electronic banking.

Several different distribution channels are used by the commercial banks. They offer their services through branch networks, automatic teller machines, the telephone and PC/Internet based home banking systems. Also channels such as car dealers, mobile branches (buses), and retailers are used for distributing bank services. Ordinary branch banking requires the customers to come to the branch, where they have access to a wide variety of banking services but have to wait in line before getting served. Telephone banking requires the customers to phone the bank.

It is more cost-effective than an ordinary branch and it is more convenient for the customer. PC banking can be used by customers who have access to and can use a personal computer and a modem, whereas Internet banking furthermore requires access to the World Wide Web (Kalakota and Frei, 2007). Early versions of PC banking were expensive, complicated and did not achieve a sufficient level of consumer acceptance, but today it is even more costeffective than telephone banking, and it is also more convenient. Besides, a larger number of more complex banking operations can easily be handled with PC and Internet banking.

According to Swanson (2010), organizational performance is the valued productive output of a system in the form of goods or services. Organizational performance can be subdivided into three categories: financial performance (profit), internal non-financial performance (productivity) and external non-financial performance (e.g., customer satisfaction). Private sector organizations strive for good financial results whereas public organizations are aimed at non-financial aims like delivering good public services to citizens (Van Loo and De Grip, 2012). To achieve performance through employees, the organization must consider them as asset and must be treated with attention so that the employees become productive. Gone are the days where an employee was given single task. Today's business environment demands people having multi skills so that they can be placed as per the need of the hour. Hence individual motivation, job design, job structure, individual competence, and appropriateness of performance goals and standards of measurement are considered important and are more directly and easily controllable.

Organizational performance, although not a precisely defined concept, is assessed in terms of the results that an organization achieves in relation to its objectives. In principle, it can be measured at the output, outcome or impact level, and, less rigorously, as the organization's compliance to rules. The process of determining the performance of an organization requires the selection and the measuring of a set of key variables that can allow the organization to detect as well as monitor its competitive position in the business in which it engages. In another words, measuring performance is also one of the important steps in the strategic control process (Wheelen and Hunger 2015). The firm's performance could be measured by various concepts, such as sales per employee, value of export, total assets and operation profit ratio. The ability of an organization to survive and succeed is influenced by various factors, some of which can and some of which cannot be controlled. Therefore the performance of an organization is a function of the controllable and uncontrollable variables (Kim and Lim, 2018). 


\subsection{Research Problem}

As one of the key elements of a company's success, selecting the proper distribution channel strategy has been a focal point in both supply chain and marketing channel structure. The distribution strategy decision is usually based on finding the most profitable way to reach a market (Ford and Mottner, 2013). Successful distribution channel strategy selection, implementation, and management cannot only help to meet the shopping needs and habits of the target customers efficiently under the cost constraints of the seller; they must also mitigate the disadvantages caused by distribution channel conflicts such as double marginalization. According to Porter (1985), organizational competitive advantage can be achieved if the firm implements a value-creating strategy that is not simultaneously being implemented by any current or potential competitors. This can be interpreted to mean that sustained competitive advantage results from strategic assets; which Barney (2011) regards as those that are internally controlled and permit the firm to formulate and implement strategies that expand its efficiency and effectiveness. A firm's distribution strategy of its products and services is such a strategic asset.

Several studies have been undertaken locally and internationally on the subject area of distribution channel strategies adopted by various local companies. Irimu (2009), undertook a research on the Effects of distribution channel strategies employed by sewing machine industry in Nigeria on channel members 2009; a case of Amedo Centres (k) Ltd. In her study, she found out that the location of the service facility is especially important for such business since many target customers may lack the funds for public transportation or they may feel psychologically uncomfortable to visit distance outlets. On her part, Alumila (2004) researched on the distribution strategies used by Health maintenance organization in Nigeria. She found out that health care customers unlike other services value the faceto-face contact with the seller and also emphasise a trustful relationship.

In Denmark, Katz and Aspeden (2007) found out that the Internet banking customers is very similar to the PC segment. The persons are connected to the Internet for the use of e-mail, for the search of information about special interests and do not put a high value on the personal relationship with the local bank, they are relatively price conscious, affluent and well-educated. This study therefore seeks to establish the effect of marketing channel distribution strategies on the banking industry companies in Nigeria.

\subsection{Research Objectives}

The research objectives were:

(i) To identify the distribution channel strategies adopted by commercial banks in Nigeria

(ii) To determine the effect of the distribution channel strategies adopted on the performance of the bank.

\subsection{Research Questions}

(i) What are the distribution channel strategies adopted by commercial banks in Nigeria?

(ii) To what extent does the adopted distribution channel strategies affect the performance of the bank?

\subsection{Research Hypothesis}

Ho2: The adopted distribution channel strategies does not have a significant effect on the performance of the bank

\subsection{Significance of the Study}

Findings of the study will be useful to researchers and scholars as it will contribute to the body of knowledge in the area of non-performing of loans. It will also assist other researchers to further their studies on areas of interest not yet exploited.

It will assist the management of commercial banks to evaluate how effective they have been in adopting appropriate distribution channel strategies of their services and products. This may enable them identify gaps in their strategies which may enhance their strategic response as a result move to effectively manage the existing strategies which will improve their financial performance. 
This study will benefit the government and especially the Ministry of Finance for making policy decisions whose overall objectives are to reduce bottlenecks in distribution of banking services and at the same time hasten the rate of growth in the banking industry sector and take advantage of the improved economy thus more lending to individuals and institutions.

It will be useful to the shareholders of the bank in evaluating the effectiveness of the banks distribution strategies as they cope with the increasingly competitive financial market locally and globally. Other organizations can also use the distribution strategies employed by the bank to improve their performance. By identifying the appropriate distribution strategies, the industry will also be able to achieve their objective much faster and growth of the individual firms.

\section{Literature Review}

\subsection{Marketing strategy}

The two dominant typologies that have emerged in the business strategy field are the Miles and Snow's (2008) typology (i.e. prospector, defender, analyzer, and reactor) and Porter's (1980) typology (i.e. cost leadership, differentiation, and focus). However, Mol's et al., (2009), observes that Porter's (1980) typology has been used extensively in marketing strategy literature probably because it captures the way in which firms create value (i.e. differentiation or low cost) and defines their scope of market coverage (i.e. focused or market-wide). They further posit that, in the marketing strategy literature, with the exception of Slater and Oslo (2011), there is a lack of comprehensive marketing strategy classification schemes. Murphy and Enis (2016) framework classify products (i.e. convenience, preference, shopping, and specialty products) and integrate the remaining marketing mix elements (price, promotion, and distribution) into this framework.

On the other hand Slater and Olson's (2011) typology of marketing strategy includes aggressive marketers, mass marketers, marketing minimizes, and value marketers. The two authors found similarities between aggressive marketers and prospectors, mass marketers and analyzers, low cost defenders and marketing minimizers, and between differentiated defenders and value marketers. Slater and Oslon (2011) also suggest that there is congruence between their marketing strategy typology and the typology proposed by Murphy and Enis (2016) -, e.g. the aggressive marketers resemble specialty product marketers; mass marketers offer broad product range, use intensive distribution, and charge low price; marketing minimizers put the lowest emphasis on marketing; while value marketers prefer to lower prices while offering high customer service.

According to Mol's et al., (2009) the aggressive marketing is that marketing strategy (characterized by high quality, innovative products with high prices and selective distribution, and investment in advertising and marketing support functions); Price leadership (characterized by a focus on price discounts to ensure that the firm/product is not underpriced and letting the price consideration drive other activities such as purchase), and Product specialization (characterized by limited and specialized product range with other business functions driven by this narrow focus). From a marketing perspective, Hunt and Morgan (2015) point out that product and price decisions are two of the most crucial strategic decisions faced by managers. However, aggressive marketing captures a more multifaceted high value, high price, and high investment in marketing function.

The importance of the relationship between marketing strategy and channel relationalism is evidenced in the strategy literature and focuses on the fit between strategy and structure (Slater and Olson, 2011). They point out that as firms try to adopt one or more of the three marketing strategies - aggressive marketing, price leadership, and product focus (specialization) - they may find that the extent of relational norms present in their marketing channels may not be equally suitable for all three strategies. Aggressive marketing strategy is characterized by high-quality innovative products, close relationships with customers, extensive marketing research and market segmentation to identify premium target markets, selective distribution, and intensive advertising (Slater and Olson, 2011). As a result, for channel partners, such strategy refers to an intimate knowledge of the market, closer involvement with both the suppliers and customers, and a willingness to invest in market research and R\&D. on the basis of the same, a high degree of relationalism in marketing channels is thus likely to foster closer ties amongst channel intermediaries, strong identification with the common goal, and an incline towards long term payoffs in comparison to a more transactional and short term orientation ( Dant and Schul, 2012). Literature on use of power business-to-business relationships have traditionally suggested that an aggressive marketing strategy may be associated with use of power by lead channel members, however, recent thinking suggests that the use of coercive power in fact results in dysfunctional outcomes (Hingley, 2005). 
Product specialization (focus) strategy, on the other hand, is characterized by a more concentrated approach towards segmenting the market and targeting a narrowly defined niche market with fewer and more specialized products (consistent with the more current service dominant logic (Lusch et al., 2007). For channel members, this strategy may translate into a shrinking business volume. Although the increased focus on segmentation and focused targeting may prove to be a significant investment of effort and resources, the outcomes may not be commensurate with the enhanced resource allocation, especially with a shrinking scope of operation and business volume. Lasser and Kerr (2016) found that firms offering differentiated and highly specialized products tended to rely more on highly involved control relationship with very close monitoring of behavior. Thus, relationalism, while conducive for aggressive market strategy, may not be as conducive for product specialization strategy.

Price leadership strategy requires a shift in focus to lower margins and high volumes. Price leadership strategy may require intensive distribution with a focus on larger markets resembling mass marketing strategy. While Slater and Olson (2011) found that mass marketing strategy is congruent with analyzer strategy, Lasser and Kerr (2016) found the cost leaders to be low in behavioral control, contractual restriction, and manufacturer coordination with medium levels of manufacturer support. While this strategy is not likely to yield significant results in the short run, they pointed out that it may have a bright future due to the enhanced market coverage. Therefore, to encourage the channel members to go along with a low price strategy, managers may need to rely heavily on relational norm among channel partners with a promise of a successful future. This approach is more likely to succeed than a strong bureaucratic stance which is typically more transactional and short term in orientation.

\subsection{Distribution Strategies in the Banking Sector}

The economic distribution channel theory posit that the normative distribution channel can be determined by exploring what the consumers want in terms of service outputs from the distribution channel, how much they are willing to pay for a given service level, how the services can be provided to them, and what the costs of the alternative distribution channels are (Stern and Sturdivant, 2006). Thus it is imperative that business units establish an appropriate distribution system that is most efficient in meeting the customers' wants. Thus, an economic distribution channel model takes a customer perspective, analyses the output from the commercial part of the different distribution channels and relates it to the customers' costs and benefits from the different levels of service output offered by the available distribution channels.

According to Frei et al., (2007), the interaction between the adoption and promotion of electronic channels by the banks and the changes in the customer segments is input to a change process where the structure of the distribution channel is adapted to the new environment. However, they note that this is not likely to happen overnight because of barriers and temporal constraints. For example, some banks will have invested in a huge branch network, which will be of no use if all or most of its customers want to switch to an electronic channel, and the customers will be tied to their present bank and its distribution channel because of habits, and perceived social, psychological and financial risks associated with switching banks. Besides, they will have to spend time searching and evaluating alternative banks in order to find a more suitable bank. Therefore, the existing distribution strategy will also influence the changes in the distribution channel structure. The change process will end when the new distribution strategy is the normative distribution channel (Bucklin, 2016).

Several different distribution channels are used by the commercial banks. They offer their services through branch networks, automatic teller machines, POS, the telephone, and PC/Internet based home banking systems. Also channels such as car dealers, mobile branches (buses), and retailers are used for distributing bank services

\subsection{Branch Network}

Ordinary branch banking requires the customers to come to the branch, where they have access to a wide variety of banking services but have to wait in line before getting served. The branch banking segment consists mainly of older, non-computer literate persons, who value personal relationships (Heskett et al., 2017). These customers value the face-to-face contact with the bank teller and emphasize a trustful relationship. They do not own a PC and do not work with information technology. As are result of the adoption of technology, this segment is still large and important but it is shrinking.

As manifested by the banks' branch network, this has been the emergent strategy for most banks. For a number of banks, this is the distribution channel structure they are used to, and this is where their competences lie. It is suitable for delivering services based on face-to-face interaction, and it targets a very large segment of bank customers. 
However, many banks might be reducing their reliance on the branch network. The problem with the strategy is that it is expensive and likely to lead to a decreasing number of customers. Growth might be maintained through mergers and acquisitions, but only a few banks will have the luck and the skills necessary for such a strategy. A likely strategy for the banks at present pursuing this strategy is therefore to combine it with an offer of electronic home banking services. For some banks the transformation will cause problems because they lack resources or because of bad timing in the promotion of the electronic channels. These banks risk being unable to match the prices of, for example, competing Internet banks (Birch and Young, 2007).

\subsection{Electronic Banking}

Telephone banking strategy has the telephone as its most important distribution channel; it relies on a more impersonal form of contact than the branch banking strategy. According to Birch and Young (2007), majority of European countries have this system in place, but they have often used it in combination with the branch banking strategy. The advantages connected with this strategy are that all people with access to a telephone are potential customers and that it is less costly than the branch banking strategy. Thus, it gives access to a large segment and a large geographical coverage without large-scale investments. It also relies on thoroughly tested and secure technology. The disadvantages, though, are that it has attracted the most price-sensitive customers (Mols, 2008), and that this segment is likely to shrink.

PC banking has many of the same qualities as the telephone channel and most banks attach decisive importance to offering some kind of customer-friendly PC bank solution. The segment attracted to this strategy is relatively small though growing, and its members are likely to be the first to adopt the Internet bank solutions. Therefore PC banking, though transitory, may be the most important channel for the banks. The reason why so many banks attach importance to offering a PC bank solution may be that survey results have shown that the least price-sensitive customers are PC bank customers, and thus, they make up a potentially very profitable segment to serve (Mols, 2008). This trend can still be explained by the early adopters' interest in the new technology and the convenience it offers rather than by an interest in using the most cost-effective distribution channel. Therefore, it is likely that PC bank customers will eventually become more price-sensitive, which is in accordance with the predictions that Internet banking is likely to make home banking customers even more price-sensitive than they are today (Birch and Young, 2007). As with the telephone and PC banking strategy, a pure Internet banking strategy requires radical changes for many banks. They have to reduce their number of branches and foster new competences. However, the strategy has the advantage that it aims at serving the fastest-growing customer segment, and thus it will be a means to gain market shares. In addition, it is a low-cost strategy, because the Internet is the cheapest distribution channel. The disadvantage is that it is difficult for Internet banks to differentiate their offerings (Birch and Young, 2007).

According Howcroft and Kiely (2005), the electronic distribution channels and especially the Internet-based version, reduce the entry barriers into retail banking. It makes it easier to cover a larger geographical area and thus multinational/global commercial banks might emerge. In the multinational version of the Internet banking strategy no further branches are needed. However, a centrally-situated branch in each country might be necessary to attract local expertise, to assist the customers in case of unexpected problems and to handle the contact with the national authorities. Problems with technical and legal security to support the exchanges over the Internet constitute a barrier to success with this strategy. It makes the Internet technology uncertain and requires the customers to exhibit a high level of trust (Angelides, 2007). Therefore, another problem might be to convince new customers that they can trust the bank, in the cases when the bank is not very well-known and has no significant physical presence (Birch and Young, 2007).

\subsection{Multiple distribution banking}

The multiple channel strategy is the most popular distribution channel strategy among. It gives customers a gentle transition from a branch banking strategy to a strategy emphasizing one of the electronic distribution channels, and it provides a good market coverage (Moriarty and Moran, 2000). It is also a way for the bank managers to hedge their bets by making a number of smaller investments in PC/Internet banking systems, while simultaneously continuing a traditional branch banking strategy.

However, the hedge strategy is not entirely without problems. Multiple channels are likely to lead to conflicts between the branches and the departments responsible for the electronic distribution channels. It can be difficult to motivate the front personnel in the branches to promote these home banking services knowing that it leads to 
cannibalization and unemployment. The strategy can also result in customer problems because they may have difficulties in accepting a wide price differential between the services offered through the branches and the services offered through for example the Internet (Moriarty and Moran, 2000).

\subsection{Marketing Strategies and Firm Performance}

The main purpose of marketing is to understand and meet customers' needs and this is achieved when all components of the marketing system, that is, suppliers and distributors, are cocoordinating efforts and working in harmony (Okoroafo, 2006). He points out those well-conceived and effective marketing activities will facilitate the achievement of typical organizational objectives such as higher sales, market share, profits and competitive advantage. Indeed, a marketing function is an important and integral part of organizational business strategy. Specifically, marketing activity in this study is based on practices associated with product, price, promotions, distribution, and finally, customer-orientation, since the customer is perceived as the focus of all marketing efforts.

According to Okoroafo and Russow (2003), sound marketing practice is an important contributor to performance in economic reform economies. Many businesses will adopt a new attitude to marketing in transition environments, formulating strategies which demonstrate a focus on customers. Thus for firms to be competitive in such environments, it is essential to conduct effective product, pricing, promotion and distribution activities, where customers are central to all marketing efforts and to the extent that these strategies are successfully implemented, they are expected to result in improved performance.

According to Day (2004), "Market-driven firms are distinguished by an ability to sense events and trends in their markets ahead of their competitors. They can anticipate more accurately the response to actions designed to retain or attract customers, improve channel relations, or thwart competitors. They can act on information in a timely, coherent manner because the assumptions about the market are broadly shared". This organizational capability has significant implications for the attainment and sustainability of competitive advantage. Businesses that possess the ability to learn rapidly about their markets and to act on that information are best positioned to achieve competitive advantage (Tuominen et al., 1997). To help an organization deal with market events and trends, internal organizational processes develop (Day, 2004). Among the organizational processes that typically develop within an organization, its strategic planning processes and the related processes it uses for analyzing market information are cited as being among the most important (Moller and Anttila, 2007).

A market oriented organization possesses the ability to generate, disseminate, and respond to information about market forces and market conditions better than their less market oriented rivals (Jaworski and Kohli, 2003). This gives a market oriented organization an important basis for building a sustainable competitive advantage by learning what buyers want, building the processes necessary to deliver the value they desire and adapting those value generating processes as market conditions change. To use these processes as the basis for competitive advantage, an organization needs to develop the capabilities to generate, disseminate, and respond to market intelligence and the processes to act on this information (Hunt and Morgan, 2005).

In addition to a market orientation, organizations need competitive strategies to help focus their efforts. According to Day (2014) "A competitive strategy specifies how a business intends to compete in the markets it chooses to serve. This strategy provides the conceptual glue that gives shared meaning to all the separate functional activities and programs". A well developed strategy, therefore, serves to coordinate the competitive actions of the firm. As one of the major pro-competitive functions in the organization, marketing has a major impact on how these strategies are formulated and how resources are allocated to implement these strategies (Hunt and Morgan, 2005). For the marketdriven firm, creating superior customer value is the objective of strategy formulation and implementation. To do this, customer value-based differentiation strategies will drive the firm's market research efforts, its selection of targetmarkets, its product development processes, and its market communications programs (Day, 2014)

According to Hunt and Morgan (2015) not all firms will develop a market-orientation. Some firms choose to focus their attention on internal issues, such as process technology and resulting efficiencies. These firms devote less time to understanding what customers value, choosing instead to focus on increasing volume. Customer needs analysis plays a relatively small role in product development in these firms. Instead, product development is typically driven by process technology capabilities which often are the result of incremental process improvements. Unlike marketdriven firms, where a focus on value (as defined by the customer) drives marketing decision making, marketing decisions in these firms often revolve around pricing issues, such as volume discounts, as the key to increasing the firm's unit sales. 
Firms that do not develop a market orientation must either develop the process technology to out-innovate rivals or achieve low cost positions (Day, 2014). These firms, although they will not develop the processes needed to generate, disseminate, and respond to market intelligence to the same degree as a market oriented firm, can be successful by combining a process focus with just enough market intelligence generation, dissemination, and responsiveness to understand where customers' needs are going and react accordingly. Day (2014) alludes to the existence of these firms when he discusses the impact of Total Quality Management (TQM) on value generation. Successful implementation of TQM gives firms a quality focus, which often coincides with what customers' desire.

\section{Research Methodology}

\subsection{Research Design}

The research design for the study was a descriptive survey research design. It was concerned about a univariate question in which the researcher was asked questions about the distribution strategies adopted by the commercial banks in Nigeria. This design provided an insight into research problem by describing the variables of interest. Crosses sectional study was used since different organizations were to be surveyed during the same time period. The cross sectional study was adopted because it provided a quick snapshot of what was going on with the variables of interest for the research problem in the different organizations.

\subsection{Population}

The population of the study consisted of the 43 marketing managers selected from 5 commercial banks in Nigeria. The selection of the commercial banks as the population of the study was that the commercial banks represents different institutions with varying capital base, branch network, distribution networks, spread of their network within the country and regionally. Further, these banks by virtue of serving different segments of the market adopted diverse distribution strategies to reach these customers. In addition, the banking sector has been experiencing intense competition both from local and international banks and one of the ways in which these banks have been able to maintain their competitiveness is through adoption of appropriate distribution strategies. Because of the number of banks (5) and staff to be surveyed (43), the same population also acted as the sample.

\subsection{Data Collection}

The study used primary and secondary data. Primary was collected through questionnaires that were to be distributed by the researcher. The questions were structured and the respondents fully informed about the purpose of data collection. The questionnaires consisted of both open ended and closed ended questions. The open-ended questions were meant to avoid limiting the respondents in answering the questions. A likert scale was also be used for close ended questions. Secondary data on the subject area was collected through annual reports and organizational publications on performance and profitability. The staff questionnaires were administered purposeful to one marketing/distribution manager or the equivalent in each bank.

\subsection{Data Analysis and Presentation}

The data was analyzed by the use of descriptive statistics to summarize and relate variables which were be attained from the administered questionnaires. The data was classified, tabulated and summarized using descriptive measures, percentages and frequency distribution tables, the hypothesis was tested using the regression tool. In accomplishing all analysis details with efficiency and effectiveness, the researcher utilized the Statistical Package for Social Sciences (SPSS Version 26) software.

\section{Data Analysis, Results, and Discussion}

\subsection{Marketing Distribution Strategies}

Marketing strategy is a method of focusing an organization's energies and resources on a course of action which can lead to increased sales and dominance of a targeted market niche. A marketing strategy combines product 
development, promotion, distribution, pricing, relationship management and other elements; identifies the firm's marketing goals, and explains how they will be achieved, ideally within a stated timeframe.

The respondents were requested to indicate the marketing distribution strategies which are employed by their bank in a five-point Likert scale. The range was, strongly disagree (1)' to strongly agree' (5). The scores of strongly disagree have been taken to represent a variable which had a mean score of 0 to 2.5 on the continuous likert scale; $(0 \leq$ S.E <2.4). The scores of moderate extent' have been taken to represent a variable with a mean score of 2.5 to 3.4 on the continuous likert scale: $2.5 \leq$ M.E. $<3.4$ ) and the score of both agree and strongly agree have been taken to represent a variable which had a mean score of 3.5 to 5.0 on a continuous likert scale;

$3.5 \leq$ L.E. $<5.0$ ). A standard deviation of $>0.9$ implies a significant difference on the impact of the variable among respondents. The results as shown in Table 4.2

Table 1. Marketing Distribution Strategies adopted by banks

\begin{tabular}{ccc}
\hline & Mean & $\begin{array}{c}\text { Standard } \\
\text { Deviation }\end{array}$ \\
\hline Aggressive marketing & 4.2105 & .9051 \\
Mass marketing & 3.9474 & 1.0891 \\
Marketing minimizers & 2.1316 & 1.2557 \\
Value marketing & 3.4474 & .8284 \\
\hline
\end{tabular}

Source: Field Survey, 2021

The findings on Table 1, indicate that the respondents agreed that they use aggressive marketing (mean 4.2105), mass marketing (mean 3.9474) and value marketing (mean 3.4474). They however, disagreed that they adopt marketing minimizers (mean 2.1316). The results indicates that the commercial banks uses different marketing strategies in order to gain competitive advantage over its competitors.

Also, the respondents were asked to indicate the distribution strategies of banking services in their organization in a five-point Likert scale. The range was, very low extent (1)' to, very great extent' (5). The scores of very low extent have been taken to represent a variable which had a mean score of 0 to 2.5 on the continuous likert scale; $(0 \leq$ S.E <2.4). The scores of, moderate extent' have been taken to represent a variable with a mean score of 2.5 to 3.4 on the continuous likert scale: $2.5 \leq$ M.E. $<3.4$ ) and the score of both great extent and very great extent have been taken to represent a variable which had a mean score of 3.5 to 5.0 on a continuous likert scale; $3.5 \leq$ L.E. $<5.0$ ). A standard deviation of $>0.9$ implies a significant difference on the impact of the variable among respondents. The results as shown in Table 2.

Table 2. Employment of Distribution Strategies

\begin{tabular}{ccc}
\hline & Mean & Standard Deviation \\
\hline Branch Network & 4.4795 & 1.2746 \\
Electronic banking & 3.5103 & .8181 \\
Multiple distribution & 4.2308 & 1.0628 \\
\hline
\end{tabular}

Source: Field Survey, 2021

The findings on the usage of various distribution strategies by the commercial banks was that, branch network (mean 4.4795), multiple distribution (mean 4.2308) and electronic banking (mean 3.5103) was used by the banks to ensure that they market their products to its customers

\subsection{Hypothesis}

$\mathbf{H}_{1}$ : The adopted distribution channel strategies have a significant effect on the performance of the bank

Ho: The adopted distribution channel strategies does not have a significant effect on the performance of the bank 
Table 3. Model Summary ${ }^{b}$

\begin{tabular}{|c|c|c|c|c|c|}
\hline Model & $\mathrm{R}$ & R Square & $\begin{array}{l}\text { Adjusted } \quad \mathrm{R} \\
\text { Square }\end{array}$ & $\begin{array}{l}\text { Std. Error of the } \\
\text { Estimate }\end{array}$ & Durbin-Watson \\
\hline 1 & $.810^{\mathrm{a}}$ & .657 & .648 & .83461 & .241 \\
\hline
\end{tabular}

\section{Source: SPSS Version 26}

a. Predictors: (Constant), Distribution Channel Strategies

b. Dependent Variable: Performance of Commercial Banks

Table 4.

ANOVA ${ }^{\text {a }}$

\begin{tabular}{lll|l|l|l|l}
\hline Model & & Sum of Squares & df & Mean Square & F & Sig. \\
\hline \multirow{2}{*}{1} & Regression & 54.603 & 1 & 54.603 & 78.387 & $.000^{\mathrm{b}}$ \\
\cline { 2 - 7 } & Residual & 28.560 & 41 & .697 & & \\
\cline { 2 - 7 } & Total & 83.163 & 42 & & & \\
\hline
\end{tabular}

Source: SPSS Version 26

a. Dependent Variable: Performance of Commercial Banks

b. Predictors: (Constant), Distribution Channel Strategies

Table 5.

Coefficients $^{\mathbf{a}}$

\begin{tabular}{|c|c|c|c|c|c|c|c|}
\hline \multirow{2}{*}{\multicolumn{2}{|c|}{ Model }} & & \multicolumn{2}{|c|}{ Unstandardized Coefficients } & \multirow{2}{*}{$\begin{array}{l}\text { Standardized } \\
\text { Coefficients } \\
\text { Beta }\end{array}$} & \multirow[b]{2}{*}{$\mathrm{t}$} & \multirow[b]{2}{*}{ Sig. } \\
\hline & & & $\mathrm{B}$ & Std. Error & & & \\
\hline \multirow[t]{2}{*}{1} & (Constant) & & .352 & .239 & & 1.476 & .148 \\
\hline & $\begin{array}{l}\text { Distribution } \\
\text { Strategies }\end{array}$ & Channel & .961 & .109 & .810 & 8.854 & .000 \\
\hline
\end{tabular}

\section{Source: SPSS Version 26}

a. Dependent Variable: Performance of Commercial Banks

\subsection{Result Summary}

$\begin{array}{lll}\mathrm{R} & = & .810 \\ \mathrm{R}^{2} & = & .657 \\ \mathrm{~F} & = & 78.387 \\ \mathrm{~T} & = & 8.854 \\ \mathrm{DW} & = & .241\end{array}$

\subsection{Interpretation of the Result}

A linear regression analysis conducted to determine the effect of the distribution channel strategies adopted on the performance of the bank. (Table 3-5) shows that there is strong positive relationship between distribution channel strategies and performance of the bank $(\mathrm{R}$ - coefficient $=.810)$. The $\mathrm{R}$ square, the coefficient of determination, shows that only $65.7 \%$ of the variation in performance of the bank can be explained by distribution channel strategies with no autocorrelation as Durbbin-Watson (.241) is less than 2. With the linear regression model, the error of estimate is low, with a value of about .83461 . The regression sum of the square 54.603 is more than the residual sum of the square 28.560 indicating that the variation is not due to chance. The F-statistics $=78.387$ shows that the model is significant.

\subsection{Decision Rule}

Reject null hypothesis (Ho) if P-Value $<0.05$ and do not reject Ho if otherwise

\subsection{Decision}

Since the P-Value $000<0.05$, we reject the null hypothesis $(\mathrm{Ho})$ and then conclude that the adopted distribution channel strategies have a significant effect on the performance of the bank. 


\subsection{Discussion of Findings}

The respondents agreed that the marketing strategies being employed by the banks were aggressive marketing, mass marketing and value marketing. The study found out that the characteristics employed by the banks was close relationships with customers, product specialization, extensive market research, selective distribution, segmentation of market, high quality innovative products and controlled relationship with customers while increased relational norm with channel partners, intensive distribution to a mass market and low behavioral control on consumers were employed by the banks to a moderate extent.

The marketing distribution channel strategies being used by commercial banks was branch network, electronic banking and multiple distribution. The respondents were in agreement that marketing through branch network strategy would result to access to a large geographical and segment market, efficient in meeting customer wants, enhance face to face with the customer, targets a large market segment, service costs to customers was higher than other networks and that it requires a high level of trust. This marketing strategy however, leads to enhanced legal and technical security challenges and being expensive to undertake than other distribution strategies.

The electronic marketing strategy targets a large market segment and that it is efficient in meeting customer wants. It does not however leads to enhanced face to face with the customer, expensive to undertake than other distribution strategies and that service costs to customer was higher than other networks. On the use of multiple marketing distribution strategy, the respondents were in agreement that it is efficient in meeting customer wants, targets a large market segment, gives access to a large geographical and segment market, it is expensive to undertake than other distribution strategies, service costs to customers is higher than other networks, leads to enhanced face to face with the customers and enhanced legal and technical security challenges. The respondents found out that the marketing distribution strategies results to increased sales, market share and profits, the bank being able to market changes more effectively and enhanced ability of the bank to generate, disseminate, and respond to market changes.

\section{Summary, Conclusion, and Recommendations}

\subsection{Summary of the findings}

From the analysis of this study, it was found that:

1. The commercial banks use different marketing strategies in order to gain competitive advantage over its competitors.

2. the adopted distribution channel strategies have a significant effect on the performance of the bank.

\subsection{Conclusion}

This study has presented the results of some descriptive survey research into the effects of marketing distribution channel strategies on a bank's performance among commercial banks in Nigeria. Effective marketing requires a clear understanding of the arena in which a firm is competing and the nature of its performance. For strategy to be truly marketing-oriented, both the definition of the competitive arena and the need for performance improvement must be demand-driven. In services in general and financial services in particular, certain characteristics, namely intangibility and complexity, affect consumer evaluation processes. As consumers become increasingly reliant on credence qualities in evaluation and as services become more complex, the process of improving firm performance becomes more difficult.

The results establish that a large majority of commercial banks attach great importance to offering one or several of the distribution channels to their customers. The distribution strategies affect the performance of commercial banks and especially with increased customer understanding, either because consumers are more knowledgeable or because the products are relatively simple, or both, then elements such as distribution channels, price and specific service features may become more important in adding value and improving its performance.

\subsection{Recommendations}

The study found out that the commercial banks adopts various marketing distribution strategies. It is therefore recommended that: 
1. The commercial banks should adopt those marketing distribution strategies that ensure the performance of the bank is improved and do away with those which adds costs so that the banks can compete effectively with the others.

2. The commercial banks distribution channels service costs vary therefore, before pricing its products, they should study what the market charges so that they set at a price which is acceptable to the current and potential customers.

3. The study established that the commercial banks use electronic banking in order to ensure that its customers carry out its transactions anywhere and anytime. So they should embrace the concept whole heartedly by adopting electronic banking as already the battle for the banks is technology usage which should be one which offers customers more features.

\section{References}

Alumila G.M (2004), Distribution strategies used by Health Maintenance organization in Nigeria, Unpublished MBA project, University of Nairobi

Barney, J.B. (2011), Firm resources and sustained competitive advantage, Journal of Management, Vol. 17 No.1, pp. $99-120$

Birch, D. and Young, M.A. (2007), Financial services and the Internet - what does Cyberspace mean for the financial services industry? Internet Research: Electronic Networking Applications and Policy, Vol. 7 No.2, pp.120-8

Bucklin, L.P. (2016), "A normative approach to the economics of channel structure", in Bucklin, L.P. (Eds), Vertical Marketing Systems, Scott, Foresman and Company, Glenview, IL, pp.159-75.

Cohen, W.M., Nelson, R.R. and Walsh, J.P. (2013), Protecting their intellectual assets: appropriability conditions and why US manufacturing firms patent or not, working paper 7552, National Bureau of Economic Research, Cambridge, MA,

Dant, R.P., and Schul, P.L. (2012), "Conflict resolution processes in contractual channels of distribution", Journal of Marketing, Vol. 56 No.1, pp.38-54

Day, G.S., Wensley, R. (2014), "Assessing advantage: a framework for diagnosing Competitive superiority", Journal of Marketing, Vol. 52 No.2, pp.1-20

Ford, J.B. and Mottner, S. (2003), Retailing in the non-profit sector: an exploratory analysis of church-connected retailing ventures, International Journal of Non-profit and Voluntary Sector Marketing, Vol. 8 pp.337-48.

Frei, F.X., Harker, P.T., and Hunter, L.W. (1997), "Innovation in retail banking", Financial Institutions Center, The Wharton School, University of Pennsylvania, Philadelphia, Working paper 97-48-B.

Greenland, S.J. (2004), Rationalization and restructuring in the financial services sector, International Journal of Retail \& Distribution Management, Vol. 22 No.6, pp.21-8

Heskett, J.L., Sasser, W.E. Jr, Schlesinger, L.A. (2017), The Service Profit Chain, The Free Press, New York, NY.,

Hunt, S.D., Morgan, R.M., (2015), "The comparative advantage theory of competition", Journal of Marketing, Vol.59, pp 1-15

Irimu S. T (2009), Effects of distribution strategies employed by the sewing machine industry in Nigeria on channel members: A case of Amedo centre (k) ltd, Unpublished MBA project, University of Nairobi

Kalakota, R., and Frei, F. (2007), Frontiers of online financial services, in Cronin, M.J. (Eds), Banking and Finance on the Internet, Van Nostrand Reinhold, New York, NY, pp.19-74.

Kim, S. and Lim, J. (2018), Environmental, generic strategies and performance in rapidly developing countries, The Academic of Management Journal, Vol 31

Lasser, W.M. and Kerr, J.L. (2016), "Strategy and control in supplier-distributor relationships: an agency perspective", Strategic Management Journal, Vol. 17 No.8, pp.613-32. 
Lusch, R.F., Vargo, S.L., O'Brien, M. (2007), "Competing through service: insights from service-dominant logic", Journal of Retailing, Vol. 83 No.1, pp.5-18.

Miles, R.E., Snow, C.C. (1978), Organizational Strategy, Structure and Process, McGraw-Hill, New York, NY.

Mols, N.P. (2009), "The behavioral consequences of PC banking", International Journal of Bank Marketing, Vol. 16 No.5, pp.195-201

Murphy, P., Enis, B. (1986), "Classifying products strategically", Journal of Marketing, Vol. 50 No.3, pp.24-42.

Okoroafo, S., Russow, L. (2003), "Impact of marketing strategy on performance: empirical evidence from a liberalized developing country", International Marketing Review, Vol. 10 No.1, pp.4-18.

Porter, M. (1985), Competitive Advantage: Creating and Sustaining Superior Performance, Free Press, New York, NY.

Slater, S.F., Olson, E.M. (2011), "Marketing's contribution to the implementation of business strategy: an empirical analysis", Strategic Management Journal, Vol. 22 No.11, pp.1055-1067.

Stern, L.W. and Sturdivant, F.D. (2006), "Customer-driven distribution systems", Harvard Business Review, Vol. 65 No.4, pp.34-41.

Van Loo and De Grip, S. (2012) "Skills, Obsolescence, Causes and Cures", International Journal of Manpower, Vol 17, pp 45-46.

Wheelen, T.L. and Hunger J.D. (2015), Strategic Management and Business Policy Prentice Hall, New York, NY. 